\author{
*УДК 336.711 \\ Смовженко Т.С., д.е.н., професор \\ Огородник В. В., к.е.н. \\ Інститут банківських технологій та бізнесу \\ ДВНЗ «Університет банківської справи»
}

\title{
СОЦІАЛЬНА ВІДПОВІДАЛЬНІСТЬ БАНКІВ 3 ДЕРЖАВНОЮ УЧАСТЮ В УКРАЇНІ
}

У статті досліджено специфіку напрямів реалізації концепції соціальної відповідальності банків 3 державною участю в Україні. У результаті проведеного дослідження визначено, що концепція соціальної відповідальності вітчизняних банків 3 державною участю включає такі структурні складові: встановлення пріоритетних рівнів та видів соціальної відповідальності, принципів та векторів їхньої реалізації. Визначено напрями розширення сфер прояву соціальної відповідальності банків з державною участю в Україні.

Ключові слова: банк, банківська діяльність, банківська система, банк 3 державною участю, соціальна відповідальність.

\section{Smovzhenko T., Ohorodnyk V. \\ SOCIAL RESPONSIBILITY IN THE UKRAINIAN STATE-OWNED BANKS}

The article is dedicated to the peculiarities of the social responsibility concepts in the Ukrainian state-owned banks, i.e. the concepts' current state, level of their implementation, and perspectives of further development. The aim of the present research is to identify the contents of the state-owned banks social responsibility concepts, outline their structure, and characterise vectors of their implementation.

It is noteworthy that under the present economic and political conditions, social responsibility of banks in general and the state-owned ones in particular has become crucial, as banks of the latter type play a leading role on the banking market accumulating more than 55\% of the Ukrainian banking assets as of 01.01.2018; consequently, it is vital to fully implement their social responsibility concepts.

The analysis of the existing state-owned banks concepts allows to arrive at conclusion that each bank has developed their own social responsibility concept (characterised by different level of elaboration) implemented by each bank individually. The research allows to claim that the social responsibility concepts of the domestic stateowned banks includes the following structural components: setting the priority levels and types of the bank's social responsibility, outlining the principles and vectors of their implementation. The following levels of the social responsibility concept implementa-

* Смовженко Т.С., Огородник В. В. 
tion are singled out: a) the basic level; b) the corporate level; c) the highest level. It is determined that the domestic state-owned banks mainly implement the social responsibility concepts at the basic and corporate levels; at the same time, the highest level of the concept implementation requires the improvement of the banks' close interaction with the NGOs, authorities and communities on local and national levels. The paper also outlines the state-owned banks social responsibility types, i.e. the external and internal social responsibility.

The article offers several principles keeping too which can ensure the effective implementation of the social responsibility concept in the Ukrainian state-owned banks: authenticity, transparency, balance, integrity, voluntariness, equality, maintaining good relationship with the stakeholders, foresight.

In addition, the study analyses the main vectors of the social responsibility concept implementation in Oshchadbank, Ukreximbank, PrivatBank, and Ukrgasbank. It is determined that domestic state-owned banks implement their social responsibility concepts in various vectors, e.g. the mission of each bank includes the concept of its social responsibility. Notably, the state-owned banks most actively follow their internal social responsibility vectors which embrace the employees personal and professional development, charity activities expanding, and the customers' financial literacy improvement.

As one of the vectors, expanding the scope of the social responsibility concept of the Ukrainian state-owned banks, it looks relevant to improve the quality, stability, and safety of access to financial services for the citizens. The research makes it possible to recommend the state-owned banks to increase the stakeholders' access to full, timely, and accurate information about financial status of the bank, keeping to the principles of integrity and complying with the ethical standards of the banking activities.

Key words: bank, banking activity, banking system, state-owned bank, social responsibility.

\section{Смовженко Т.С., Огородник В.В. \\ СОЦИАЛЬНАЯ ОТВЕТСТВЕННОСТЬ БАНКОВ С ГОСУДАРСТВЕННЫМ УЧАСТИЕМ В УКРАИНЕ}

В статье исследована специфика направлений реализации концепции социальной ответственности банков с государственным участием в Украине. В результате проведенного исследования установлено, что концепция социальной ответственности отечественных банков с государственным участием включает следующие структурные составляющие: установление приоритетных уровней и видов социальной ответственности, принципов и векторов их реализации. Определены направления расширения сфер проявления социальной ответственности банков с государственным участием в Украине.

Ключевые слова: банк, банковская деятельность, банковская система, банк с государственным участием, социальная ответственность.

Постановка проблеми у загальному вигляді та її зв'язок 3 важливими науковими і практичними завданнями. У сучасних 
економічних умовах України саме банки з державною участю відіграють провідну роль на ринку банківських послуг (у даних банках зосереджено більше 55 \% банківських активів станом на 01.01.2018 p. [1]). Зважаючи на посилену увагу до проявів соціальної відповідальності бізнесу та взаємозв'язок банківської діяльності з діяльністю кожного економічного суб'єкта, важливим видається повноцінне впровадження концепції соціальної відповідальності вітчизняними банками $з$ державною участю.

Аналіз останніх досліджень, у яких започатковано вирішення проблеми. Питання становлення і розвитку вітчизняних банків з державною участю в Україні знайшло своє відображення у роботах таких вчених як: Вовчак О.Д., Примостка Л.О., Чмутова I.M., Оніщенко В.В., Погореленко Н.П. Особливості впровадження концепції соціальної відповідальності у практику українських компаній та банківських установ розглядаються у наукових працях Грішнової О. [2], Колота А. [2], Денис О. [3], Півняка Г. [4] Гражевської Н. [5], Мостепанюк А. [5], Харламова А., Орлова Н. Водночас, залишається не розкритим питання соціальної відповідальності вітчизняних банків 3 державною участю, що й обумовлює актуальність проведеного дослідження.

Цілі статті. Мета дослідження полягає у визначенні структурних складових концепції соціальної відповідальності банків 3 державною участю, а також в характеристиці основних векторів іiі реалізації.

Виклад основного матеріалу дослідження 3 обгрунтуванням отриманих наукових результатів. За сучасних складних економічних умов усе більшої важливості набуває соціально відповідальна діяльність банківських установ, а особливо банків 3 державною участю, які виконуючи покладені на них завдання зі стимулювання соціально-економічного розвитку, здійснюють підтримку реалізації інфраструктурних проектів державного значення, кредитування пріоритетних галузей економіки тощо.

Перш за все, коротко охарактеризуємо вітчизняні банки 3 державною участю. Станом на 01 жовтня 2018 року в Україні функціонують чотири банки з державною участю: Ощадбанк, Укрексімбанк, Укргазбанк та Приватбанк. При цьому, лише Ощадбанк та Укрексімбанк від самого початку свого існування виступають бан- 
ками 3 державною участю. Натомість, два інших банки перейшли до державної власності: Укргазбанк у 2009 році внаслідок глобальної фінансової кризи 2008-2009 pр., а Приватбанк наприкінці 2016 року 3 метою недопущення банкрутства найбільшого приватного банку.

Далі зазначимо, що кожен з вітчизняних банків $з$ державною участю має свою специфічну концепцію соціальної відповідальності, що відрізняється глибиною розробки та впровадження. Водночас, необхідно окреслити загальні структурні складові концепції соціальної відповідальності у банках з державною участю (рис. 1).

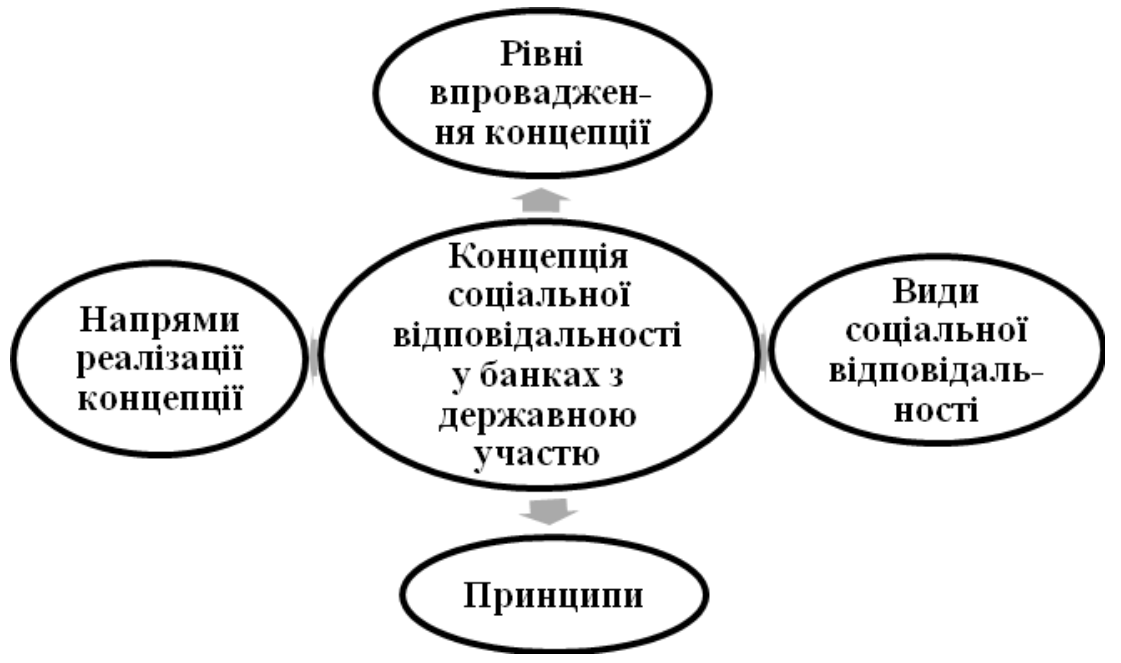

Рис. 1. Структурні складові концепції соціальної відповідальності банків з державною участю в Україні

Джерело: складено автором на основі аналізу [2], [4], [5].

3 рисунку 1 видно, що концепція соціальної відповідальності вітчизняних банків 3 державною участю включає: встановлення пріоритетних рівнів та видів соціальної відповідальності, принципів та напрямів їхньої реалізації. Прийнято виділяти такі рівні впровадження концепції соціальної відповідальності:

- базовий рівень (дотримання вітчизняних нормативноправових актів стосовно сплати податків, виплати заробітної плати 
персоналу та підвищення його кваліфікації);

- корпоративний рівень (впровадження кодексу корпоративної культури, забезпечення належних умов праці та відпочинку працівників, їх додаткове страхування та пенсійне забезпечення тобто усе, що передбачає посилення соціальної складової у функціонуванні банківської установи, а також якість надання банківських послуг та ефективність діяльності);

- вищий рівень: а) реалізація соціальних проектів та програм, які не пов'язані з основною сферою діяльності банку, спільно 3 громадськими організаціями, місцевими громадами та органами влади тощо; б) впровадження принципів соціальної відповідальності при наданні клієнтам банківських послуг.

Вітчизняні банки з державною участю активно впроваджують концепцію соціальної відповідальності на базовому та корпоративному рівні (про що свідчать численні тренінгові програми 3 підвищення кваліфікації працівників, додаткові заходи в системі мотивації). Адже, дана діяльність не вимагає жодних особливих зусиль зі сторони банків, водночас, їі реалізація передбачає прямі вигоди у вигляді вищої залученості та лояльності персоналу. Вищий же рівень впровадження концепції потребує налагодження взаємодії з недержавними громадськими організаціями, громадськістю та органами влади.

Наступним етапом нашого дослідження $є$ виокремлення принципів реалізації концепції соціальної відповідальності у банках $з$ державною участю в Україні:

a) принцип достовірності - надання усім зацікавленим сторонам правдивої інформації, що стосується як безпосередньо банківської діяльності, так і звітності банку;

б) принцип відкритості та прозорості - передбачає повне i своєчасне розкриття інформації стосовно діяльності банку та його звітності клієнтам, акціонерам, партнерам та контролюючим органам (це не означає розголошення банківської таємниці чи службової інформаціі);

в) принцип збалансованості - передбачає знаходження певного балансу між відкритістю та прозорістю банку, а також досяг- 
нення максимальної вигоди для акціонерів 3 урахуванням принципів «комерції» та інтересів клієнтів;

г) принцип доброчесності - суворе дотримання як управлінцями, так і звичайними працівниками банку своїх посадових обов'язків, норм вітчизняного законодавства, а також запобігання корупції та зловживанням посадових осіб;

д) принцип добровільності - добровільне прийняття банком на себе відповідальності щодо реалізації соціальних проектів та програм;

е) принцип рівноправності - забезпечення балансу інтересів акціонерів та клієнтів (мета акціонерів - максимізація прибутку, клієнтів - забезпечення вільного доступу до якісних банківських продуктів / послуг за оптимальною ціною), а також роботодавців, працівників та держави;

ж) принцип підтримки гарних взаємовідносин із зацікавленими сторонами - передбачає покращення та оновлення банківських продуктів / послуг завдяки вчасному виявленню зміни вподобань та потреб різних клієнтів (через діалог із зацікавленими сторонами), а також діяльність банку у якості благодійника чи спонсора у різних проектах, направлених на незахищені верстви населення чи соціальні проблеми тощо, що у майбутньому забезпечить конкурентні переваги у вигляді лояльного ставлення клієнтів;

3) принцип далекоглядності - передбачає участь банків у реалізації соціальних та екологічних проектів 3 метою забезпечення гідних умов існування майбутнім поколінням.

Таким чином, дотримання вказаних принципів, на думку автора, дасть можливість ефективно реалізовувати концепцію соціальної відповідальності у вітчизняних банках з державною участю, що буде та відповідати усім вимогам світового співтовариства (ISO 26000, GRI тощо).

Дослідження структурних складових концепції соціальної відповідальності банків з державною участю в Україні передбачає виокремлення основних видів соціальної відповідальності даних банків, а саме: зовнішньої соціальної відповідальності (спонсорство, благодійність, дотримання прийнятих у суспільстві норм та 
стандартів, дотримання прав людини, сприяння природоохоронній діяльності, реалізація соціальних проектів спільно з місцевою владою та громадою, доброчесні відносини з усіма зацікавленими сторонами, задоволення попиту споживачів у якісних товарах та послугах) та внутрішньої соціальної відповідальності банків (забезпечення належних умов праці та іiі безпечність, сприятливий внутрішній соціальний клімат у колективі, додержання принципів та стандартів корпоративної культури, організація системи мотивації персоналу, стабільна та гідна заробітна плата, впровадження програм підвищення кваліфікації персоналу, здійснення відрахувань на недержавне пенсійне страхування).

Зазначимо, що представлено лише основні характеристики зовнішньої та внутрішньої соціальної відповідальності вітчизняних банків 3 державною участю. 3 метою більш детального дослідження та визначення специфіки реалізації концепції соціальної відповідальності кожним банком з державною участю окремо, проаналізуємо вектори реалізації даної концепції Ощадбанку, Укрексімбанку, Приватбанку та Укргазбанку (табл. 1).

3 даних представлених у таблиці 1 видно, що вітчизняні банки 3 державною участю реалізують концепцію соціальної відповідальності через різноманітні вектори, наприклад, при розробці місії та стратегії кожного з банків враховано концепцію соціальної відповідальності. Водночас, не один із проаналізованих банків із державною участю не подає нефінансову звітність, хоча у 2011 році Приватбанк (ще перебуваючи у приватній власності) випустив свій Соціальний звіт, розроблений у довільній формі без відносності до жодного міжнародного стандарту звітності. Поруч із цим, Укрексімбанк уже впродовж багатьох років відображає інформацію про соціальну відповідальність у звітності банку.

Обрані вітчизняними банками 3 державною участю пріоритети соціально відповідальної діяльності (спонсорство та благодійництво, навколишне середовище, освіта, розвиток персоналу та покращення умов праці, благоустрій територій) свідчать про впровадження, у більшості банків, саме американської моделі соціальної відповідальності (для якої характерними є переважання філантропії та незначний вплив держави). 
Економічні науки". - Серія "Облік і фінанси" - Випуск 15 (57). - 2018.

Таблиця 1

Вектори реалізації концепції соціальної

відповідальності у банках з державною участю в Україні

\begin{tabular}{|c|c|c|c|c|}
\hline Показник \Банк & 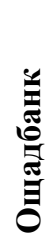 & 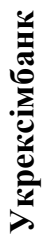 & 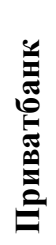 & 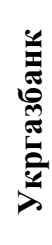 \\
\hline $\begin{array}{l}\text { Місія та стратегія банку розроблені з ураху- } \\
\text { ванням соціальної відповідальності }\end{array}$ & + & + & + & + \\
\hline $\begin{array}{l}\text { Інформація про соціальну відповідальність } \\
\text { відображається у звітності банку }\end{array}$ & - & + & - & - \\
\hline Банк подає нефінансову звітність & - & - & - & - \\
\hline $\begin{array}{l}\text { Інформація про прояви концепції соціальної } \\
\text { відповідальності широко висвітлюється на } \\
\text { сайті }\end{array}$ & + & + & + & + \\
\hline Програми з розвитку персоналу & + & + & + & + \\
\hline $\begin{array}{l}\text { Заходи з покращення умов праці та соціально- } \\
\text { го захисту працівників }\end{array}$ & + & + & + & + \\
\hline Впровадження принципів «зеленого офісу» & + & + & + & + \\
\hline $\begin{array}{l}\text { Відображення інформації про вплив профіна- } \\
\text { нсованих банком проектів }\end{array}$ & - & - & - & + \\
\hline Реалізація державних соціальних програм & + & + & - & - \\
\hline Фінансування програм з енергозбереження & + & + & - & + \\
\hline $\begin{array}{l}\text { Реалізація проектів з підвищення фінансової } \\
\text { грамотності населення }\end{array}$ & + & + & + & + \\
\hline $\begin{array}{l}\text { Підвищення доступності банківських послуг } \\
\text { для осіб із спеціальними потребами }\end{array}$ & + & - & - & - \\
\hline $\begin{array}{l}\text { Впровадження кредитних програм з пільгови- } \\
\text { ми умовами }\end{array}$ & + & - & - & + \\
\hline Програми з благоустрою територій & + & + & + & + \\
\hline Благодійництво та спонсорство & + & + & + & + \\
\hline
\end{tabular}

Джерело: складено автором на основі аналізу [6], [7], [8], [9] 
Таким чином, банками 3 державною участю в Україні найбільш активно реалізуються напрями внутрішньої соціальної відповідальності, а також спонсорство та підвищенням фінансової грамотності населення. Тож, необхідним $є$ розширення векторів реалізації концепції соціальної відповідальності кожним із банків 3 державною участю, що відповідатиме сучасним вимогам економіки та суспільства.

Одним із напрямів розширення сфер прояву концепції соціальної відповідальності у практиці вітчизняних банків з державною участю виділимо підвищення доступу громадян до фінансових послуг. Дане питання має неабияку актуальність в Україні, оскільки станом на початок 2018 року лише 53 \% громадян віком старше 15 років мають вільний доступ до банківських послуг (тоді як у Польщі даний показник становить 78 \%, в Угорщині - 72 \%, у Бразилії - $68 \%$, а у Туреччині - 65 \%). Тож, на нашу думку, саме вітчизняні банки 3 державною участю (Ощадбанк, Укрексімбанк, Приватбанк та Укргазбанк) мають найбільше можливостей, як провідники державної політики уряду та власники значної частки банківського ринку України, для підвищення доступності банківських послуг для населення. Крім того, саме Ощадбанк виступає одним 3 каталізаторів розвитку безготівкових розрахунків у країні, що також сприятиме реалізації даного напряму. Завдяки cashlessрішенням банку та його партнерів Mastercard та Visa технологія безконтактної оплати працює в широкій торгівельно-сервісній мережі, транспорті, сфері дозвілля та освіти.

Крім того, вважаємо за доцільне посилити увагу банків 3 державною участю до такого вектору реалізації концепції соціальної відповідальності, як повне, своєчасне та достовірне інформування стейкхолдерів щодо фінансового стану банків (високі стандарти розкриття інформації), доброчесність та дотримання етичних стандартів банківської діяльності, що в кінцевому підсумку сприятиме підвищенню довіри до банківської системи України загалом та лояльному ставленню клієнтів до банків.

Висновки. Отже, охарактеризувавши структурні складові 
концепції соціальної відповідальності банків з державною участю та проаналізувавши основні вектори іiі реалізації можемо зробити висновок, що, у переважній більшості, банки орієнтовані на реалізацію освітніх проектів, проектів у галузі навколишнього середовища та культурних цінностей, а також програми пільгового кредитування, управління персоналом, якість надання банківських послуг та ефективність своєї діяльності. Подальша популяризація концепції соціальної відповідальності та розширення переліку соціальних ініціатив банків 3 державною участю може значно вплинути на покращення показників соціально-економічного розвитку країни.

1. Основні показники діяльності банків України [Електронний ресурс] : / Національний банк України. - Режим доступу: https://bank.gov.ua/

2. Колот А. М., Грішнова О. А. та ін. Соціальна відповідальність: теорія і практика розвитку: монографія [за наук. ред. д.е.н., проф. А. М. Колота]. - К.: КНЕУ, 2012.

3. Denys O. Foreigh experience in corporate social business responsibility shaping / O. Denys, Z. Lapishko // Enterprises facing new economic challenges. - Cracow: University of Economics, 2010. - P. 29-33.

4. Соціальна відповідальність влади, бізнесу, громадян / Монографія за загальною редакцією професора Г.Г. Півняка. - Дніпропетровськ, 2014. - Том 1. - С. 378-382.

5. Гражевська Н., Мостепанюк А. Корпоративна соціальна відповідальність як чинник нагромадження новітніх форм капіталу в сучасній ринковій економіці / Н. Гражевська, А. Мостепанюк // Вісник Київського національного університету імені Тараса Шевченка. Серія «Економіка». - 2018. - №2 (197). - с. 12-19.

6. Офіційний сайт АТ «Ощадбанк» [Електронний ресурс] : / АТ «Ощадбанк». Режим доступу: https://www.oschadbank.ua/ru/.

7. Офіційний сайт ПАТ КБ «ПриватБанк» [Електронний ресурс] : / ПАТ КБ «Приватбанк». - Режим доступу: https://privatbank.ua/about.

8. Офіційний сайт АТ «Укрексімбанк» [Електронний ресурс] : / АТ «Укрексімбанк». - Режим доступу: https://eximb.com/ukr/about/.

9. Офіційний сайт АБ «Укргазбанк» [Електронний ресурс] : / АБ «Укргазбанк». Режим доступу: http://www.ukrgasbank.com/about/. 